\title{
THE IMPLICATIONS OF ADOPTING THE MODEL OF COMPLETE HARMONIZATION (A CASE STUDY)
}

\author{
ROBERT STEFANICKI*
}

\begin{abstract}
INTRODUCTION
A new challenge for national legislation and law enforcement organs is basing certain directives on the model of complete harmonization. It is a source of inspiration owing to the fact that it will have a strong impact on the enforcement of contract law. European Parliament and Council Directive 2005/29 concerning unfair business-to-consumer commercial practices in the internal market and amending Council Directive 84/450/EEC, Directives 97/7/EC, 98/27/EC and 2002/65/EC of the European Parliament and of the Council and Regulation (EC) No 2006/2004 of the European Parliament and of the Council forms a common legal framework for the whole European Union in relation to issues of commercial practices applied by traders in sales and the promotion of goods and services. The essence of the Directive consists of a general ban on unfair practices. The substantive aspect of the legal solutions means the Member States cannot derogate the transposition process, so there shall be no modification of the level of protection in domestic law provided by the Directive. The material has been limited to the Court's interpretation of the 2005 Directive. This is the first legislative solution in EU law regulating the integrity of the sphere of fair market practices, aimed directly at consumers. The conclusions of the legal ruling may be a valuable guideline for national legislation and jurisprudence, and a contribution to legal discourse.
\end{abstract}

I.

In connection with the reliance of the Directive on the complete harmonization clause, significant difficulties appear in the practical application of the transposed legislation ${ }^{1}$. The question is raised of the more

DOI: $10.2478 /$ wrlae-2013-0036

* Professor of Law; Department of Commercial and Business Law, University of Wroclaw. robert.stefanicki@prawo.uni.wroc.pl

1 Christiane Wendehorst,'Das deutsche Umsetzungskonzept für die neue Verbraucherkreditrichtlinie' (2011) 2 Zeitschrift für europäisches Privatrechts $267 \mathrm{ff}$ and 
precisely defined scope of Directive on unfair B2C commercial practices, while at the same time the boundaries of national derogations are set out in detail - effective in all conditions - allowing for a comprehensive ban. These issues concern the judgment of the Court on 9 November 2010 (C-540/08). The reference for a preliminary ruling stems from an application for interim relief made by Mediaprint Zeitungs- und Zeitschriftenverlag GmbH \& Co $\mathrm{KG}$, in which it seeks an injunction against Österreich-Zeitungsverlag $\mathrm{GmbH}$ for anti-competitive use of a bonus in principle unlawful under national law in the form of a competition prize. The Mediaprint Zeitungsund Zeitschriftenverlag $\mathrm{GmbH} \& \mathrm{Co} \mathrm{KG}$ case is the third in a series of references in which national courts $a^{2} k^{2}$ the Court whether national prohibitions of combined offers are compatible with Directive 2005/29. One of the main questions which distinguishes the present case from previous ones, and which must therefore be the subject of careful legal consideration, is whether such an examination of compatibility is also possible where the purported regulatory objective of the national provision in question is to protect both media diversity and competitors.

II.

The dispute in the main proceedings concerns a situation in which the daily newspaper 'Österreich', belonging to the defendant in the main proceedings, organised the election of the 'footballer of the year' and invited the public to join in that competition, by internet or by means of a voting slip appearing in a 2007 edition of the newspaper. Participation in that competition gave the possibility of winning the prize of dinner with the footballer chosen. Considering that that possibility of gain, subject to the purchase of the newspaper, constituted an unlawful bonus for the purposes of Paragraph $9 \mathrm{a}(1)(1)$ of the $\mathrm{UWG}^{3}$, Mediaprint applied to the Handelsgericht Wien for an injunction against the defendant in the main

literature cited therein. The present model also does not mean that this process will cover all legal solutions and relevant aspects, Delphine Lahet, Frédérique Julienne, 'La Directive européenne sur les contrats de crédit aux consommateurs: quelles opportunités pour les consommateurs européens et les opérations transfrontières?' (2010) 2 Revue Internationale de Droit Economique 185.

${ }^{2}$ Case C-261/07 VTB-VAB NV v Total Belgium NV [2009] and C-299/07 Galatea BVBA v Sanoma Magazines Belgium NV [2009] ECR I-2949; C-304/08 Plus Warenhandelsgesellschaft [2010], not yet published.

${ }^{3}$ Paragraph 9a of the Federal Law on Unfair Competition of 1984 (Bundesgesetz gegen den unlauteren Wettbewerb 1984) (BGB1. I, 448/1984), as amended by BGB1. I, 136/2001 ('the UWG'), reads: (1) Any person who, in carrying on a competitive commercial activity, 1. announces, in public advertisements or other communications destined for a large number of persons, that he is granting to consumers free advantages (bonuses) associated with products or services, or offers, announces or grants to consumers free advantages (bonuses) linked to periodicals or 2. proposes, announces or grants to undertakings free advantages (bonuses) associated with products or services, may be subject to an action for an injunction and damages. That also applies where the gratuitous nature of that advantage is concealed by overall prices for the products or services, by fictitious prices for a bonus or in any other manner.

See http://www.dbj.co.at/VorlesungBrugger/Vorlesung2009/neuntedoppelstunde.pdf, p. 13; Andreas Wiebe, Georg Kodek, Kommentar zum UWG: Gesetz gegen den unlauteren Wettbewerb (Manzsche Verlags- und Universitätsbuchhandlung 2009). 
proceeding to bring that practice to an end. Whereas that court upheld the application, the Oberlandesgericht Wien to which the case was referred on appeal held that the prohibition on sales with bonuses could apply only if the gain announced was capable of encouraging the public to buy the newspaper. In the view of the appeals court, such an 'attraction effect' was not produced in this case, taking account in particular of the fact that the public could also participate in the competition via the internet ${ }^{4}$. In addition to consumer protection, the prohibition serves both to maintain effective competition and to protect media diversity. The opinions expressed by the European Commission were such that the general prohibition would act as a safety net and future-proof the directive $\mathrm{e}^{5}$. By preventing competitors from outbidding one another with further ancillary benefits, it is intended above all to protect competitors who, because of their lesser economic resources, are not in a position to promote sales of their products by means of free bonuses. Such protection is justified in view of the importance of the media in forming opinions in a democratic society. The primary purpose of the Austrian 'prohibition of bonuses' since it came into being has been to prevent the purchasing decision of consumers being influenced nonobjectively by bonuses and the real price ${ }^{6}$ of the main item from being hidden by the bonuses, such that the customer is misled. Earlier Austrian authorities referred to the Court to support the validity of national bans on combined offers. The Court held in connection with the compatibility with the free movement of goods of a Netherlands prohibition of bonuses that the offering of free gifts as a means of sales promotion may mislead consumers as to the real prices of certain products and distort the conditions on which genuine competition is based. The Court concluded that legislation which restricts or even prohibits such commercial practices for that reason is therefore capable of contributing to consumer protection and fair trading.

III.

Mediaprint then appealed (revision) on a point of law against the Handelsgericht Wien decision to the Oberster Gerichtshof. In its order for reference, that court begins by observing that Paragraph $9 \mathrm{a}(1)(1)$ of the UWG lays down a general prohibition on sales with bonuses, which is

\footnotetext{
${ }^{4}$ One of the most difficult challenges in the future will be navigating the various and disparate laws relating to the Internet throughout the world. For example, as American and European concepts of individual privacy and data ownership continue to diverge, transactions costs could increase, and some businesses may even be driven out of certain markets, as notes Joshua Sibble, 'Recent Developments in Internet Law' (2011) 4 Intellectual Property \& Technology Law Journal 15.

5 Giuseppe Abbamonte, 'The unfair commercial practices directive and its general prohibition' in Stephen Weatherill, Ulf Bernitz (eds), The regulation of unfair commercial practices under EC Directive 2005/29: New rules and new techniques (Hart Publishing Oregon 2007) 11.

${ }^{6}$ Steffen Huck and Brian Wallace, 'The impact of price frames on consumer decision making' Office of Fair Trading May 2010

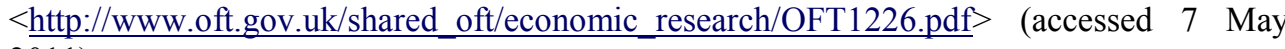
2011)
} 
aimed at ensuring both the protection of consumers and the maintenance of effective competition. That having been stated, it is uncertain whether the Directive, which by contrast has as its objective the protection of consumers and exclusively governs relations between them and undertakings, precludes such a provision. The UWG ban includes exceptions that relieve the general prohibition: Because Subparagraph 1 above shall not apply where the advantage consists in: an accessory currently used in association with the product or accessory services that are usual practice; samples; advertising objects characterised by a very visible and durable designation of the undertaking which makes the advertising; advantages of low value (bonuses) or minor objects of low value, provided the latter are not designed to form a collection the value of which exceeds the sum of the values of the various individual objects given; a given sum of money, or a sum to be calculated in a given manner, which does not accompany the product; a given quantity - or a quantity simply to be calculated by fraction - of the same product; the supply of information or advice or the granting of a right to participate in a competition ${ }^{7}$ in which the value of the individual participation ticket is located in a specific sum ${ }^{8}$. However, the court had doubts as to whether the prohibition referred to in Paragraph 9(a)(1) of the UWG is in compliance with Directive 2005/29. Therefore, the dispute in the main proceedings and the questions were referred for a preliminary ruling.

\section{IV.}

The Oberster Gerichtshof therefore stayed the proceedings and referred the following questions to the Court for a preliminary ruling (art. 267 Treaty on the Functioning of the European Union ${ }^{9}$ ): Do Articles 3(1) and 5(5) of Directive 2005/29/EC or other provisions of that Directive preclude a national provision which makes it illegal to announce, offer or give bonuses, free of charge, with periodicals and newspapers, and to announce bonuses, free of charge, with other goods or services, apart from exhaustively specified exceptions, without it being necessary in any particular case to consider whether such a commercial practice is misleading, aggressive or otherwise unfair, even where that provision serves not only to protect consumers, but also serves other purposes which are not covered by the material scope of the directive, for example, the maintenance of media diversity ${ }^{10}$ or the protection of weaker competitors ${ }^{11}$ ? The question

\footnotetext{
${ }^{7}$ A promotional game, it does not apply to advantages accompanying periodicals.

${ }^{8}$ Calculated by dividing the total value of the prizes at stake by the number of participation tickets distributed does not exceed EUR 0.36 and the total value of the prize at stake does not exceed EUR 21600 ; that may be done only by means of the advertiser's own participation tickets.

${ }_{9}^{9}$ OJ C 115/47 [2008].

10 Brian C Hill 'Measuring media market diversity: concentration, importance, and pluralism' Federal Communications Law Journal

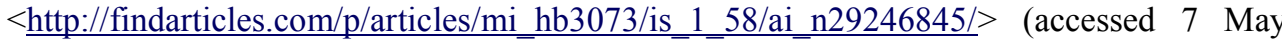
2011).

${ }^{11}$ Robert Lande, Neil Averitt, 'Consumer Sovereignty: A Unified Theory of Antitrust and Consumer Protection Law' (1997) 2 Antitrust Law Journal 713; Robert Lande, Neil Averitt, 'Using the 'Consumer Choice' Approach to Antitrust Law' (2007) 1 Antitrust Law Journal 175.
} 
may also be asked of whether the interpretation should be geared more to the protection of existing competitors than to the stimulation of competition $^{12}$. If the first question is answered in the affirmative: Is the chance of taking part in a prize competition, which is acquired with the purchase of a newspaper, an unfair commercial practice within the meaning of Article 5(2) of Directive 2005/29/EC merely because that chance is, for at least some of those to whom the offer is addressed, not the only, but the decisive reason for purchasing the newspaper?' By its first question, the referring court asks, in essence, whether the Directive must be interpreted as precluding a national provision which lays down a general prohibition on sales with bonuses and is designed not only to protect consumers but also pursues other objectives, such as, for example, the safeguarding of pluralism of the press and protection of the weakest competitors. In order to reply to the question referred, it is necessary first of all to determine whether sales with bonuses, which are the subject of the prohibition at issue in the main proceedings, constitute commercial practices within the meaning of Article 2(d) of the Directive and are therefore subject to the rules laid down by that directive.

V.

The move towards principle-based rules in the Directive is likely to have a important impact on enforcers in the implementation stage ${ }^{13}$. The issue of fairness of business practices lies in the sphere of social relations, which is unsuitable for regulation so deep and of an overly-rigid casuistic scheme. The nature of the relationships covered by this regulation requires a flexible legal structure capable of adapting to the changing reality ${ }^{14}$. Article 2(d) of the Directive gives a particularly wide definition to the concept of commercial practices. It provides that business-to-consumer commercial practices means any act, omission, course of conduct or representation, commercial communication including advertising and marketing, by a trader, directly connected with the promotion, sale or supply of a product to consumers. The Directive is characterised by a particularly wide scope of ratione materiae which extends to any commercial practice directly connected with the promotion, sale or supply of a product to consumers.

\footnotetext{
${ }^{12}$ Some experience from the United States in a recent Supreme Court case reveals that seventy years after passage of the American regulation (Robinson-Patman Act), courts remain unable to reconcile the Act with the basic purpose of antitrust laws to protect competition and consumer welfare. The language in the Act regarding competitive injury has resulted in the protection of competitors, at the expense of competition overall and consumer welfare. There is no point in further efforts to reconcile the Act with the antitrust laws in general, Deborah Garza, Jonathan Yarowsky, Bobby Burchfield, Stephen Cannon, Dennis Carlton, Makan Delrahim, Jonathan Jacobson, Donald Kempf, Stanford Litvack, John Shenefield, Debra Valentine, John Warden, Antitrust Modernization Commission Report and Recommendations (Stratford, Connecticut 2007) 322.

${ }^{13} \mathrm{C}$ Twigg-Flesner, D Parry, 'The challenges posed by the implementation of the directive into domestic law_- UK perspective' in Stephen Weatherill, Ulf Bernitz (eds) (n 5) 215.

${ }^{14} \mathrm{R}$ Stefanicki, Prawo reklamy w świetle przepisów ustawy o zwalczaniu nieuczciwej konkurencji na tle prawnoporównawczym (Ars boni et aequi 2003) 59.
} 
The sixth recital of the Directive states: This Directive approximates the laws of the Member States on unfair commercial practices, including unfair advertising, which directly harm consumers' economic interests and thereby indirectly harm the economic interests of legitimate competitors. In line with the principle of proportionality, this Directive protects consumers from the consequences of such unfair commercial practices where they are material but recognises that in some cases the impact on consumers may be negligible. It neither covers nor affects the national laws on unfair commercial practices which harm only competitors' economic interests or which relate to a transaction between traders; taking full account of the principle of subsidiarity, Member States will continue to be able to regulate such practices, in conformity with Community law, if they choose to do so. Promotional campaigns, such as those at issue in the main proceedings, which enable consumers to take part free of charge in a lottery subject to their purchasing a certain quantity of goods or services, clearly form part of an operator's commercial strategy and relate directly to the promotion thereof and its sales development. In all the judgments on the interpretation of Directive 2005/29 the Court of Justice found combined offers to be one of the practices covered by this act.

VI.

Since Directive 2005/29 fully harmonizes the rules relating to unfair business-to-consumer commercial practices, Member States may not adopt stricter rules than those provided for in the Directive, even in order to achieve a higher level of consumer protection ${ }^{15}$. The Court of Justice assigns fundamental importance to Art. 4 of the Directive ${ }^{16}$. It provides: Member States shall neither restrict the freedom to provide services nor restrict the free movement of goods for reasons falling within the field approximated by this Directive. The Court has consistently held that each of the Member States to which a directive is addressed is obliged to adopt, within the framework of its national legal system, all the measures necessary to ensure that the directive is fully effective, in accordance with the objective which it pursues. The implementation of the Directive needs to be seen in the context of the wider regulatory debate. The Court of Justice has traditionally held that the appropriate implementation of a Directive into domestic law does not necessarily require that its provisions be incorporated formally and verbatim in express, specific legislation. Rather, it is necessary that the national law brought into force to implement the Directive should meet the requirements of legal clarity and legal certainty in order to ensure that effect is given to the whole of the Directive's programme when the national law is

\footnotetext{
15 Thus, for example Ch Wendehorst, B Zöchling-Jud, Verbraucherkreditrecht (Manzsche Verlags und Universitätsbuchhandlung 2010) 5. At the same time, the concept of complete harmonization is not fully transparent and clearly clarified, see Bartosz Kurcz, Dyrektywy Wspólnoty Europejskiej i ich implementacja do prawa krajowego (Zakamycze 2004) 86ff.

16 Jules Stuyck, 'The interaction between the Unfair Commercial Practices Directive and Competition Law' in R Stefanicki (ed) Current Tendencies in Consumer Law (Wydawnictwo Uniwersytetu Wrocławskiego 2010) 211.
} 
applied by the courts and authorities of the respective Member States ${ }^{17}$. In the interpretation of Directive 2005/29 the Court of Justice has consistently respected the requirements of complete harmonization. It should be noted that the prohibition in question of combined offers in the UWG constitutes a special rule which has no counterpart in Directive 2005/29. Because of the underlying rule-exception principle, the national provision has a different general structure from Directive 2005/29. It is first and foremost this reversal of the general scheme which raises doubts as to compatibility with that Directive, the relevant factor being less the formal structure of the provision itself - if the national legislature is allowed a certain margin of discretion in connection with transposition - than the normative statement made in that national provision. It does not correspond substantively with the provisions of Directive 2005/29.

\section{VII.}

The Court of Justice, as did the Advocate General, took into account it that Article 5 of Directive 2005/29 provides that unfair commercial practices are to be prohibited and sets out the criteria on the basis of which practices may to be classified as being unfair when interpreting the regulatory structure of Directive. Article 5(1) prohibits unfair commercial practices. Article 5(2) sets out in detail what precisely is meant by 'unfair'. It states that a commercial practice is unfair if, first, it is contrary to the requirements of 'professional diligence' and, second, it 'materially distorts' the economic behaviour of consumers. Under Article 5(4), unfair commercial practices are, in particular, those which are misleading (Articles 6 and 7) or aggressive (Articles 8 and 9) ${ }^{18}$. Article 5 refers to Annex I and the commercial practices listed there, which shall in all circumstances be regarded as unfair ${ }^{19}$. The same single list applies in all Member States ${ }^{20}$. Also, recital 17 of the Directive states it is desirable that those commercial practices which are in all circumstances unfair be identified to provide greater legal certainty. Lists of unfair clauses make it easier for traders, consumers, courts and other authorities to determine the meaning of the

\footnotetext{
${ }^{17}$ Case C-96/95 Commission v Germany [1997] ECR I-1653; Commission v Italy (C-49/00) [2001] ECR I-8575; Commission v Italy (C-410/03) [2005] ECR I-3507.

18 The level of detail in the 'mini' general clause turns it into an extensive set of precise rules, leaving little scope for deviation between national legal systems. Huge Collins, 'Harmonization by example: European laws against unfair commercial practices' (2010) 1 Modern Law Review 103.

19 Critical remarks on the black list: Geraint Howells, 'Co-regulation's Role in the Development of European Fair Trading Laws' in Huge Collins (ed), The Forthcoming EC Directive on Unfair Commercial Practices: Contract, Consumer \& Competition Law Implications (Kluwer Law International2004) 124; Jules Stuyck, Evelyne Terryn, Tom Van Dyck, 'Confidence through fairness? The new directive on unfair business-to-consumer practices in the internal market' (2006) 43 Common Market Law Review 130.

20 About the possible assessment of the model: Norbert Reich, 'Full harmonization of EU consumer law - fiction or friction? - Some problem areas' in Robert Stefanicki (ed) (n 16) 145. The author discusses the issue of consequences of the full harmonization of the "black list" and possible paths to a grey list.
} 
general clause ${ }^{21}$. Annex I therefore contains a full list of all such practices. These are the only commercial practices which can be deemed to be unfair without a case-by-case assessment against the provisions of Articles 5 to 9 . The list may only be modified by a revision of the Directive ${ }^{22}$. The Austrian authorities have raised the issue of the protective functions of the prohibition in the UWG. In addition to consumer protection, the prohibition serves both to maintain effective competition and to protect media diversity. By preventing competitors from outbidding one another with further ancillary benefits, it is intended above all to protect competitors who, because of their more minimal economic resources, are not in a position to promote sales of their products by means of free bonuses. Such protection is justified in view of the importance of the media in forming opinions in a democratic society ${ }^{23}$. The court found that even if the national provision at issue in the main proceedings does essentially pursue the maintenance of pluralism of the press in Austria, it is important to note that the possibility of Member States maintaining or establishing in their territory measures which have as their aim or effect the classification of commercial practices as unfair on grounds relating to maintenance of the pluralism of the press does not appear amongst the derogations from the scope of the Directive set out in the sixth and ninth recitals and in Article 3 thereof.

\section{VIII.}

Even if exceptions (Paragraph $9 \mathrm{a}(2)$ of the UWG) are liable to restrict the scope of the prohibition of commercial practices consisting in the linking of an offer of bonuses with the purchase of goods or services, the fact remains that, because of its limited and pre-defined nature, such an exception cannot take the place of the analysis, which must of necessity be undertaken having regard to the facts of each particular case, of the 'unfairness' of a commercial practice in the light of the criteria set out in the Directive, where, as here in the main proceedings, that practice is not listed in Annex I thereto. Where a commercial practice falling within the scope of the Directive does not appear in Annex I to the latter, that practice can be regarded as unfair, and thus prohibited, only after a specific assessment, particularly in the light of the criteria set out in the Directive. The possibility of participating in a prize competition, linked to the purchase of a

${ }^{21}$ Hans-Wolfgang Micklitz, Jules Stuyck, Evelyne Terryn, Cases, Materials and Text on Consumer Law (Hart Publishing 2010) 591.

22 The Member States are not allowed to extend the list of prohibited commercial practices contained in Annex I. Were they permitted to do so, that would have the effect of circumventing the maximum harmonization which the Directive is intended to achieve, thereby frustrating the objective of legal certainty, http://ochronakonsumenta.prawo.uni.wroc.pl/forum/index.php?topic=337.0; $\quad$ Robert Stefanicki, Nieuczciwe praktyki handlowe w świetle prawodawstwa Unii Europejskiej dyrektywa 2005/29 (Difin S.A. 2007) 203.

${ }^{23}$ Oliver Castendyk, Egbert Dommering, Alexander Scheuer, European media law (Kluwer Law International 2008) 53. As long as the rights of individuals are protected, it is the role of each State to decide how to form its public space, Lautsi and others $v$ Italy, application no. 30814/06 (ECHR, 11 March 2011), http://www.echr.coe.int/echr/resources/hudoc/lautsi_and_others_v_italy.pdf (accessed 7 May 2011). 
newspaper, does not constitute an unfair commercial practice within the meaning of Article 5(2) of the Directive, simply on the ground that, for at least some of the consumers concerned, that possibility of participating in a competition $^{24}$ represents the factor which determines them to buy that newspaper.

IX.

On those grounds, the Court hereby rules: 1. Directive 2005/29/EC (...) must be interpreted as precluding a national provision, such as that at issue in the main proceedings, which lays down a general prohibition on sales with bonuses and is not only designed to protect consumers but also pursues other objectives; 2 . The possibility of participating in a prize competition, linked to the purchase of a newspaper, does not constitute an unfair commercial practice within the meaning of Article 5(2) of Directive $2005 / 29$, simply on the ground that, for at least some of the consumers concerned, that possibility of participating in a competition represents the factor which determines them to buy that newspaper. Basing the Directive on the model of complete harmonization and reduction of the personal scope of consumer protection can in its implementation lead to unfunctionality of the acquis EU law. In its Judgment of 11 March $2010^{25}$ the Court of Justice held that: Directive 2002/21/EC of the European Parliament and of the Council of 7 March 2002 on a common regulatory framework for electronic communications networks and services and Directive 2002/22/EC of the European Parliament and of the Council of 7 March 2002 on universal service and users' rights relating to electronic communications networks and services must be interpreted as not precluding national legislation, such as Article 57(1)(1) of the Polish Law on Telecommunications of 16 July 2004, in the version applicable to the facts in the main proceedings, which prohibits making the conclusion of a contract for the provision of services contingent on the conclusion, by the end-user, of a contract for the provision of other services. However, Directive 2005/29/EC (...) must be interpreted as precluding national legislation which, with certain exceptions, and without taking account of the specific circumstances, imposes a general prohibition of combined offers made by a vendor to a consumer.

\section{CONCLUSION}

The Commission had ambitious goals to include various spheres in the model of complete harmonization, such as in the example of the 8

\footnotetext{
${ }^{24}$ Some economists and lawyers further contended that effective competition did not require dozens of little firms, but instead could occur with relatively few firms in a market. If effective competition could occur without many small firms in a market, then courts did not need to interpret antitrust law to protect small businesses at the expense of consumers (Deborah Garza et al. (n 12) 34).

${ }^{25}$ Case C-522/08 Polish Telecom SA in Warsaw v President of the Office of Electronic Communications not yet published.
} 
October 2008 Proposal for a Consumer Rights Directive ${ }^{26}$. This attempt failed. The Commission's Proposal aims at simplifying and consolidating the existing legislation in the area of consumer contract law, on the basis of a fully harmonized set of key internal market aspects of consumer contract law. Contrary to the initial Commission proposal for full harmonization of EU legislation in all consumer rights fields, the Committee on the Internal Market and Consumer Protection of the European Parliament on 1 February 2011 voted to adopt a mixed approach of minimum ${ }^{27}$ and maximum ${ }^{28}$ harmonization, which would fully harmonize areas such as information requirements, delivery deadlines and a right of withdrawal from distance and off-premises sales. The aim is to ensure transparency for businesses and consumers, while leaving Member States free to retain higher standards in other areas, notably in relation to remedies for "lack of conformity" ${ }^{29}$. In accordance with art. 4 of the text adopted at the sitting of the European Parliament on 23 June $2011^{30}$, Member States may not maintain or introduce, in their national law, provisions diverging from those laid down in this Directive, including more or less stringent provisions to ensure a different level of consumer protection unless otherwise provided in this Directive. On the other hand, according to the Commission's proposal the policy option would strongly improve the quality of legislation and the level of consumer protection legislation, particularly in distance and off-premises transactions, as it would remove inconsistencies and loopholes by setting common rules and definitions ${ }^{31}$. There has been a failure so far to codify at EU level the entirety of law regarding unfair competition, although this is a matter of prime importance both for the single market as well as for forming high standards of consumer protection. From this perspective, special importance should be assigned to Directive 2005/29, which in my opinion is one of the most important items of consumer legislation in European Union

26 Brigitta Jud, Christiane Wendehorst, Neuordnung des Verbraucherprivatrechts in Europa? Zum Vorschlag einer Richtlinie über Rechte der Verbraucher (MANZ'sche 2009) 2.

${ }^{27}$ Most recent judgement of the Court on 16 June 2011 in case C-65/09 Gebr. Weber GmbH v Jürgen Wittmer, and C-87/09 Ingrid Putz v Medianess Electronics GmbH, not yet published.

${ }_{28}^{28}$ Most recent judgment of the Court on 12 May 2011 in Case C-122/10 I, not yet published.

${ }^{29}$ During the discussion the view is also raised that a general EU-wide harmonisation with a number of exceptions is necessary to create transparency that would benefit businesses and consumers alike, by simplifying life for businesses and allowing them to expand their market shares while also ensuring broader choice, price competition and clarity on rights for consumers. Partly mandatory provisions of substantive laws that may only be modified in favour of the consumer: Michael Martinek, 'Unsystematische Überregulierung und kontraintentionale Effekte im Europäischen Verbraucherschutzrecht oder: Weniger wäre mehr, in Systembildung und Systemlücken' in Stefan Grundmann (ed), Kerngebieten des Europäischen Privatrechts (Mohr Siebeck 2000) 530.

${ }^{30}$ Report: Schwab (A7-0038/2011), P7_TA-PROV(2011) 0293.

31 Commission staff working document accompanying the proposal for a directive on consumer right, Impact Assessment Report, http://ec.europa.eu/consumers/rights/docs/impact_assessment_report_en.pdf (accessed 7 May 2011).

Fernando Gomez Gomez, Juan José Ganuza, 'An Economic Analysis of Harmonization Regimes: Full Harmonization, Minimum Harmonization or Optional Instrument?', Conference in Leuven, 14-15 January 2011: A European Optional Contract Law: Policy Choices (conference materials). 
law in recent years. The principle of shared competence between the Union and the Member States applies in the area of consumer protection, so EU legislative measures should be carefully justified and necessary. The farreaching consequences discussed in the paper justifies posing questions about the best level of consumer protection and which harmonization regime should be chosen for it. 